Peršić, M., \& Halmi, L. (2017). Non-financial information and integrated reporting in the hospitality industry: Case study of Croatia. Copernican Journal of Finance \& Accounting, 6(3), 95-109. http://dx.doi.org/10.12775/CJFA.2017.019

\author{
Milena Peršićc \\ University of Rijeka \\ LAHORKA HALMI ${ }^{* *}$ \\ Karlovac University of Applied Sciences
}

\title{
NON-FINANCIAL INFORMATION AND INTEGRATED REPORTING IN THE HOSPITALITY INDUSTRY: CASE STUDY OF CROATIA
}

Keywords: Directive 2014/95/EU, non-financial information, sustainability, integrated reporting, hospitality industry, Croatia.

J E L Classification: M41, M48, Q56, D81.

Abstract: Subsequent to the Directive 2014/95/EU (EUDNFI) and Croatian Accounting Act (CAA), available non-financial information disclosed by Croatian hospitality companies in non-financial (sustainability) reports were analysed for their breadth and quality using the content analysis method The results of preliminary research of hospitality industry were used in order to explore the specifics of non-financial reporting in the hospitality industry, using case study method. Results reveal the highest scores among the quality principles is timeliness, among areas are environment, labour practice, and community/society, and an overall score to be 7.67 (out of 30). The lowest scores of quality principles were reliability and comparability, whereas areas were product

Date of submission: August 11, 2017; date of acceptance: November 9, 2017.

* Contact information: milena.persic@fthm.hr, Faculty of Tourism and Hospitality Management, Accounting Department, University of Rijeka, Primorska 42, p.p. 51410 Opatija, Croatia, phone: +385 51294 698; ORCID ID: http://orcid.org/0000-0002-6668-6856.

** Contact information: lahorka.halmi@vuka.hr, Business Department, Karlovac University of Applied Sciences, Trg J. J. Strossmayera 9, 47000 Karlovac, Croatia, phone: +38547843546. 
and human rights. The results point to a need for establishing a framework for disclosing non-financial information in reports to make them useful to internal and external users. Therefore, relevant opinions of experts, bodies and associations, such as CSR Europe, International Integrated Reporting Council, GRI's Corporate Leadership Group, will be considered in creating a model, with a particular emphasis on the globally accepted sustainability accounting standards.

\section{INTRODUCTION}

EU is moving towards greater transparency of companies' data, as of 2016 all Member States have transposed the provisions of Directive 2014/95/EU for the disclosure of non-financial information (EUDNFI, 2016) into their legislation. Under the scope of the Directive fall all those companies, which fall into the category of large undertakings with public interest, with either a balance sheet of total $€ 20$ mil (or a net turnover of $€ 40$ mil.), or if an average number of employees exceeds 500 during a financial year (CSREU 2017, part II; EUDNFI, 2016, Article 19a). Strategic accounting (Jones, Atkinson, Lorenz \& Harris, 2012; Hoque, 2006) is oriented toward collecting and recording financial and non-financial information relevant for establishing reporting system (De Villiers, Rinaldi \& Unerman, 2014; Eccles \& Spiesshofer, 2015; EY, 2014; GRI, 2016; IFAC, 2015; IIRC, 2013; PWC, 2012, 2015) in accordance with the national legislative requirements (CAA, 2016). The results of preliminary research carried out in 2016 on the sample of listed Croatian companies registering 400 and more employees between 2014 and 2016 and publicly presenting non-financial reports, pointed to the conclusion that disclosed non-financial information are mainly "story-tellers", past-oriented, qualitatively stated, generally not presenting a cause-effect relationships, thus indicating a need for significant improvements in sustainability reporting (Peršić \& Halmi, 2016, pp. 181-200).

\section{LITERATURE REVIEW}

Disclosed non-financial information was analysed for the GRI principles defining report quality of publicly disclosed non-financial information, i.e. accuracy, balance, clarity, comparability, reliability and timeliness (GRI, 2016, pp. 7-16), in order to enhance the relevance, consistency and comparability (EUDNFI, 2014, recital 21) of these reports. Research will focused on the minimum of elements to be disclosed, based on seven-steps recommended by CSR Europe (CSREU, 2017, part II), taking into account the research results of the GRI's Corpo- 
rate Leadership Group (CLGir, 2016), elements of the sustainability accounting standards provided by the Sustainability Accounting Standard Board (SASB, 2017), proposal of the International Integrated Reporting Council (IIRC, 2013) and as well as guiding principles and major requirements of integrated reporting (IR Framework, 2013, 5).

As integrated reporting is a relatively new and comprehensive reporting framework, a suitable methodological framework will be used in the case study method, founding the research in the results of related researches (Camodeca \& Almici, 2017, pp. 121-135; Carels, Morun \& Padia, 2013, pp. 947-961; Dumitru, Glavan, Gorgan \& Dumitru, 2013, pp. 24-39; Eccless \& Serafeim, 2014, pp. 1-15; Gorgan, Dumitru \& Gorgan, 2014, pp. 111-118). Strategic focus implies consideration of the liaison between strategy and value creation, i.e. the organization's capacity to harness its strategy in value creation over time (Serafeim, 2016, p. 14). Company's overall strategy has to be visualized through strategic goals and specific strategic initiatives in order to provide comprehensive and useful information for stakeholders, regardless of them being or not in accordance with the principle of conciseness (Eccles \& Serafeim, 2014, pp. 14-15).

Materiality is the most important part in selecting, connecting and assessing the relationships between information (Mio, 2016, Fig 1.1.). In integrated reporting system a great emphasis is on material issues, which are to be visible within a business model value chain framework (Eccless \& Serafeim, 2014, pp. 15-16). Material aspects and boundaries of company's business operations has to be viewed in terms of long-term efficiency and socially responsible business, taking into account the key needs of internal stakeholders (top management, board of managers, vice presidents board), managed by business experience committee and supported by expertise provided by the national bodies (e.g. Croatian Business Council for Sustainable Development - CBCSD and Croatian Institute for Corporate Social Responsibility - IDOP).

When determining company's key material aspects and strategic goals, an emphasis ought to be on the application of sustainability principles, potential effects on the environment, and the cooperation with the local community, employees and society (Hoque, 2017, pp. 241-248). The materiality matrix has to be defined at the level of all organisational units, taking into account environmental, social and material aspects, viewed through the importance of the identified key stakeholders and economic company's operations effect (IIRC, 2016, pp. 10-20). 
Qualitative characteristics of information (reliability, completeness, consistency, comparability, connectivity) are considered as a foundation for the assessing the effect of company's ability to create value over time (IR, 2016, p. 20). In that context, integrated reporting is focused on demonstrating a compliance with legal and other requirements, particularly with the provision of GRI G4 framework, where emphasis is on protection and rational use of resources, pollution prevention, reduction of waste and adequate waste management, improvement of energy efficiency, as well as on purchase of energy-saving products and services (GRI G4, 2015).

\section{METHODOLOGY AND RESEARCH PROCESS}

A content analysis was performed on sustainability reports published by three largest Croatian hospitality companies, which are required to apply the framework of EUDNFI and its other specific requirements. The focus is on assessing the achieved level of information quality disclosed in non-financial reports in accordance with the main objectives presented in the EUDNFI, and brought into force through the new Croatian legislative requirements (CAA, 2016). Only few companies in the hospitality industry fit into these criteria that disclose non-financial information (Adris Annual Report 2015 \& 2016; Plava Laguna Annual Report 2015 \& 2016; Valamar Riviera Integrated Company Annual Report and Corporate Social Responsibility 2015 \& 2016.), which could be further analysed.

Croatian hospitality company "Valamar Riviera" has been publishing integrated reports since 2015 (Valamar, 2015, 2016) and these will be analysed for the assessment of the quality of non-financial information, using case study method. A special emphasis will be on the specifics of hospitality industry activities and their impact on the achieved performance and further development, adhering to the needs of long-term profitability, social justice and environmental protection (EUDNFI, recital 3), in a way to achieve the aspiration of comparability and consistency of-non-financial information (EUDNFI, recital 15). Regarding the specifics of the selected Croatian company's business model in hospitality industry, characteristic of capitals on the input and output sides, as well as the outcomes will be analysed as a basis for upgrading the existing integrated reporting (IR) framework. 


\section{RESEARCH RESULTS}

The quality of the identified indicator(s) was analysed as defined by the GRI Standards' reporting principles (GRI, 2016, pp. 7-16), with a special emphasis on the environmental and social indicators, the latter being further subgrouped into human rights, labour practice, community/society and product. The analysis was grounded in a simple recording of the presence of an indicator(s) in the reports, regardless of them being disclosed as quantitative or qualitative indicators, or if there was just one or several of the indicators from the (sub-) groups disclosed. The score of 0.00 points to "no data", referring to the original sources not providing reliable evidence to support assumptions or complex calculations (GRI, 2016, p. 15).

As presented in the Table 1, quality assessment was conducted for 6 quality principles (accuracy, balance, clarity, comparability, reliability and timeliness) ranging from $0-5$, and 5 areas/categories (environment, human rights, labour practice, community/society and product), ranging from $0-6$, with an emphasis on the overall score which could range from 0-30 (5 areas/categories multiplied by 6 quality principles). The results of the analysis show that the highest quality principles' score is linked with the principles of timeliness (3), followed by accuracy (2.33) and clarity (2) (out of possible 5). Areas/categories of environment, labour practice and community/society are equally positioned ( 2 out of 6 ), while human rights (1) and product responsibility (0.67) are positioned considerably lower. Generally, both areas/categories and quality principles scores fall into the lower section of the respective scales, whereas the overall score compared to its possible maximum is extremely low. Namely, the overall quality score is 7.67 (out of 30 ), which is mostly affected by low rating of quality principles of comparability and reliability ( 0 out of 5), as well as the balance ( 0.33 out of 5$)$. 
Table 1. Results of the Content Analysis of Croatian Hospitality Industry Annual Reports

\begin{tabular}{|l|c|c|c|c|c|c|}
\hline \hline $\begin{array}{r}\text { Areas / } \\
\text { / Categories }\end{array}$ & Environment & $\begin{array}{c}\text { Human } \\
\text { rights }\end{array}$ & $\begin{array}{c}\text { Labour } \\
\text { practice }\end{array}$ & $\begin{array}{c}\text { Community / } \\
\text { /Society }\end{array}$ & Product & $\begin{array}{c}\text { Average score - } \\
\text { principles } \\
\text { (range 1-5) }\end{array}$ \\
\hline \hline Accuracy & 1 & 1 & $\mathbf{2}$ & $\mathbf{2}$ & 1 & $\mathbf{2 . 3 3}$ \\
\hline Balance & 1 & 0 & 0 & 0 & 0 & 0.33 \\
\hline Clarity & 1 & 1 & $\mathbf{2}$ & $\mathbf{2}$ & 0 & $\mathbf{2 . 0 0}$ \\
\hline Comparability & 0 & 0 & 0 & 0 & 0 & 0.00 \\
\hline Reliability & 0 & 0 & 0 & 0 & 0 & 0.00 \\
\hline Timeliness & $\mathbf{3}$ & 1 & $\mathbf{2}$ & $\mathbf{2}$ & 1 & $\mathbf{3 . 0 0}$ \\
\hline $\begin{array}{l}\text { Average score- } \\
\text { areas /categories } \\
\text { (range 1-6) }\end{array}$ & $\mathbf{2 . 0 0}$ & 1.00 & $\mathbf{2 . 0 0}$ & $\mathbf{2 . 0 0}$ & 0.67 & $\mathbf{7 . 6 7}$ \\
\hline
\end{tabular}

S o u r c e : authors processing.

The research results indicate that a minor number of companies in Croatian hospitality industry disclose non-financial information in annual reports, and that the quality of those information is not satisfactory according to the national accounting regulation (CAA, 2016, art. 21a) which is grounded in the EUDNFI requirements.

\section{DISCUSSION AND LIMITATION}

The outcome of the research will be demonstrated by assessing the achieved level of integrated reporting employed in Croatian hospitality industry (Valamar, 2016), following the framework of the 7 guiding principles (strategic focus; connectivity of information; stakeholder relationships; materiality; conciseness; reliability and completeness; consistency and comparability), as well as 8 integrated report content elements (organisational overview and external environment; governance; business model; risks and opportunities; strategy and resource allocation; performance; outlook; basis of presentation) (IR Framework, 2013, p. 5) and the relevant interaction between presented financial and nonfinancial information. Instead of complying with the IR framework (IR, 2013) by International Integrated Reporting Council (IIRC) in preparing 
their integrated report, Valamar Riviera applied the GRI G4 (GRI G4, 2015) reporting guidelines for sustainability reporting. For this purpose an integrated reporting model for the hospitality industry was created by employing the information disclosed in the Valamar Riviera integrated report.

\section{PRESENCE OF GUIDING PRINCIPLES THE ANALYSED INTEGRATED REPORT}

Strategic focus is clearly pointed out in the chairman and CEO's introductory messages (Valamar, 2016, pp. 4-7). The Company's overall strategy until 2020 is laid out in the integrated report, so the Company's future orientation can be visualized through strategic goals and specific strategic initiatives (Valamar, 2016, pp. 36-122). Although it provides comprehensive and useful information for stakeholders, with 174 pages the report exceeds the recommended framework of 70 pages (Eccles \& Serafeim, 2014, p. 14). This is not in accordance with the principle of conciseness and it would be more appropriate to disclose separately Strategy from integrated report on the Company's web pages, whereas only relevant links ought to be indicated in the integrated report itself.

Stakeholder relationships have already been emphasized in the introduction of the report, where the stakeholders are invited to submit their comments and suggestions for the integrated report presented on the company's website (www.valamar.riviera), and using the ability of communication through the e-mail address (integratedreport@valamar.com), following the premise that "continuous dialogue with stakeholders is an important part of our corporate social responsibility efforts integrated in Valamar Riviera's business strategy" (Valamar, 2016, pp. 11, 29), the main stakeholders are presented in the figure 1 .

The starting point and the purpose of company's activities is based on the relationship with guests by using surveys or guest opinion research, by raising awareness on the environmental issues, by involvement in charity events and by preparing newsletters. As guest's satisfaction is closely related to employee's satisfaction, surveys on corporate culture and climate research are systematically implemented, using communication through monthly corporate magazine (printed and web editions), daily, weekly and monthly department meetings as well as workers' meetings and annual party. 
Figure 1. Valamar Riviera key and related stakeholders

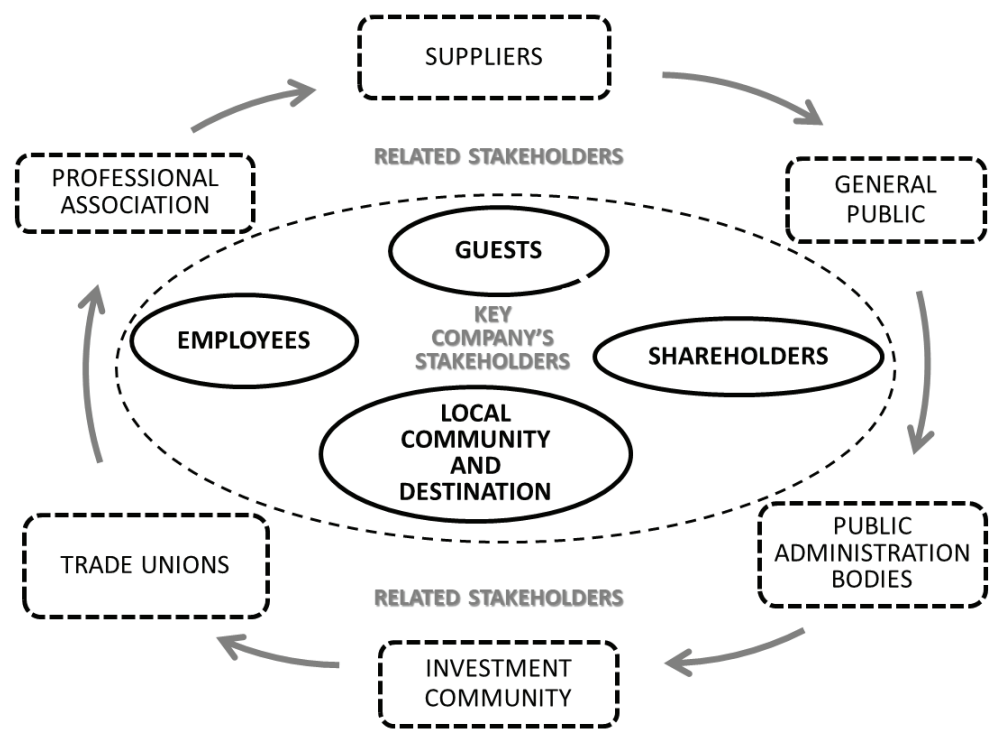

S o u r c e: Valamar, 2016, p. 30.

Shareholders obtain information from financial reports, corporate web site and printed magazines, as well as the Annual Shareholder's General Meeting. Special attention is given to the communication with the local community and destinations in which company is located, its participation in the tourist board's activities, its collaboration in the organization of the destination events and investment projects, as well as to the active participation in charity activities. In addition to the distinguished relationships with the key company's stakeholders, the relationship with related stakeholders is also attended to. Special emphasis is given on the communication with the suppliers, out of which $95 \%$ are from Croatia with a significant emphasis on the long-term collaboration and partnership.

Signed collective agreement and collaboration with the "work council" on all key issues related to employees' rights are the main link with the trade unions. Of a particular importance are relationships with various professional associations which could promote company's professional interests, such as Croatian Employers' Association (HUP), Croatian Camping Union (KUH), Association Of Employers in Croatian Hospitality (UPUH), Croatian Chamber of Economy (HGK) and regional Chambers in Pula \& Dubrovnik, Association Of Croatian 
Travel Agencies (UHPA), Croatian Meeting Professionals Association (HUPKT), Alumni of the Faculty of Tourism and Hospitality Management (ALUMNI), Croatian Association of Corporate Treasurers (HUKR), Croatian Association of Financial Analysts (HUFA), Croatian Business Council for Sustainable Development (HRPSOR), American Chamber of Commerce in Croatia, and others.

Collaboration on the development of investment projects, student scholarships and dialogue related to legislative initiatives are results of communication with the public administration bodies. Transparent communication with all investors on the capital market (non-deal road shows, meetings and conferences, "investors' day", corporate web site, etc.), different kinds of collaboration with development and commercial banks/creditors and proactive communication with analysts constitute relations with the investment community. The company is also actively involved in the general public life through press releases, corporate website and company magazine. Quality communication with stakeholders and appreciation of their proposals has definitely contributed to being recognized as the leading Croatian hospitality company in social, human and environmental responsibility (Valamar, 2016, pp. 5, 30-31, 85).

Main list of material aspects which are the subject of observation are economic effect, market presence, contribution to the community (economic, social, employment), increase in the local employment rate with the focus on permanent seasonal workforce, employee training and education, creating competitive working conditions, dialogue with the employee representatives, local community, energy (improving energy efficiency and using renewable energy sources, continued GHG reduction), water (using recycled water), wastewater and waste, ethical commitment and transparency and responsible development of tourism. Subsequently identified KPIs (measurable monitoring indicators for the upcoming periods) were identified in accordance with the company's defined strategy, goals and objectives (Valamar, 2016, pp. 29-30).

The starting point is based in company's policies which present the commitment to be the hospitality market leader in Croatia in terms of service quality, guest and user satisfaction, caring for the interests of employees, company and local community, environmental protection and resource management by adopting a high level of service quality and adhering to the principles of sustainable development. The report provides information related to the achievement of general and specific goals related to quality, safety, environment and energy, employees' training, labour law compliance and caring for employees, support 
for the local community and interests and protection of children, which will be presented through the company's business model and value chain.

\section{BUSINESS MODEL AND ITS ELEMENTS IN THE ANALYSED INTEGRATED REPORT}

Company's business model is based on the idea of simultaneous management of hospitality properties and destinations, ensuing the sustainability and social responsibility principles in creating new value, in long-term decision making and in daily practices. Special emphasis is placed on appreciation guest experience management in development and maintenance of hospitality assets, continuous improvement of operating management (in hotels, campsites and resorts), producing high quality service, with aim of securing a high return on investment.

A particular emphasis is put on co-operation with the destination management at the national (Croatian National Tourist Board), regional (Istria and Kvarner Tourist Boards) and local (Poreč, Vrsar, Funtana, Tar Vabriga, Labin, Raša, Krk, Baška and Dubrovnik Tourist Board) level, aiming to become an active partner in the destination value chain by developing local economy through continually contributing to the increase for the destination image, achieving destinations' sustainability development strategic goals, and thus becoming a leader of the development of tourism in Croatia in the future. Business model and its elements of integrated report prepared by employing the information disclosed in Valamar Riviera's sustainability report are presented in figure 2.

The company's business model ought to be considered in interaction with types of resources and their allocation onto the inputs sides (financial, manufactured, human, intellectual, social capital and relationships), in accordance with the company's specific business activities, organisational overview and governance, taking into account the requirements of external natural and business environment, ranging from the local community level (destination in which company operate) to the company's position in the tourism market. The business model also includes the framework for finding new opportunities in relation to those which have already been realised and presented in a way to assess the achieved position in the national business environment.

The following potential risks (Valamar, 2016, pp. 147-153) presented the integrated report should also be considered as an important part of company's development: financial risks (foreign exchange risk, interest rate risk, credit risk, price risk, liquidity risk, share-related risks), business risk (risks threat- 


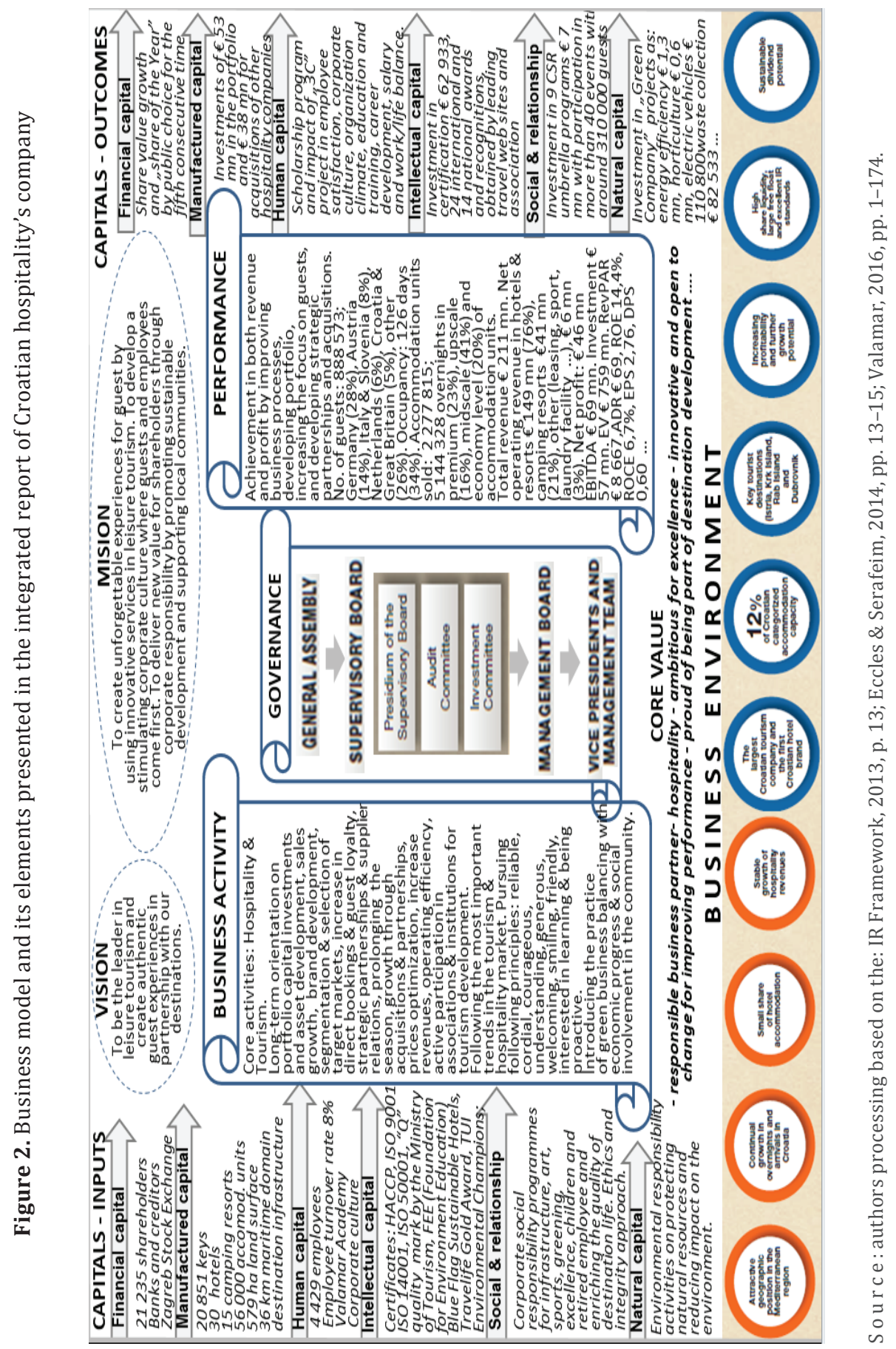


ening its competitiveness and future stability), operational risks (direct or indirect losses that arise form inadequate or wrong internal or external processes and information exchange), global risks (global financial crisis, terrorism threats, security and political instability) and compliance risks (changes in tax laws and other regulations as is a very serious threat). Risks and opportunities are also presented in the strategic determinants, adhering to the vision, mission, goals and core value elements, all being focused on creating prerequisite for achieved higher level of future performance, by employing sustainability development principles.

A conclusion can be made that just the overall quality score itself ( 7.67 out of 30) indicates a great potential yet to be fulfilled in defining specific indicators for the hospitality industry, thus improving comparability of company's results by providing a quality of information that facilitate the comparison of sustainability information and results.

\section{LiMITATION}

The main limitation of this and other researches on this topic in Croatia is that there are not enough big companies as defined by EUDNFI and CAA, that do disclose sustainability reports. In addition to this, there is insufficient number of disclosed integrated reports within the hospitality industry for testing the proposed reporting model.

\section{CONCLUSIONS AND FUTURE RESEARCH}

Valamar Riviera has been chosen for case study because it is the only and first hotel company to be disclosing sustainability reports in the hospitality industry in Croatia, thus being an ideal choice for modelling the elements of integrated reports relevant for hospitality industry. In modelling the integrated report framework, a particular emphasis was put on applying sustainability principles in the company's business activities, identified in the disclosed sustainability reports, prepared by using the GRI G4 reporting guidelines framework (GRI G4, 2015) instead of the IR framework (2013). There are many difficulties in recognising the elements relevant for disclosing capitals on the input and output side of integrated report, as defined by the strategic orientation and business model. An interdisciplinary team of experts is needed in order to ground the integrated report in realistic observations of the relationship between stakehold- 
ers in creating added value as the most important relationship, with the aim of achieving sustainability development goals and to increase company's image in its business environment.

Future research should focus on the quality of sustainable reporting and benchmarking, based on the provisions of the EUDNFI and national accounting legislation as a source of information for external user. As the quality of externally presented non-financial information should be ensured through internal sources, special emphasis ought to be on researches oriented towards connecting the accounting tools and IT possibilities with the needs of information users specific to the hospitality industry. Information prepared within the framework of an internal accounting (responsibility accounting) is primarily oriented toward needs of internal user, yet they are also a very important input into the system of non-financial reporting prepared for external users, as well as for strategic decision making process, so that they can be connected with the information coming from external sources (strategic accounting).

\section{REFERENCES}

CAA (2016). Croatian Accounting Act, consolidated text - published in the Official Gazette (OG) NO 78/15, 134/15 and 120/16.

Camodeca, R., \& Almici, A. (2017). Implementing Integrated Reporting: Case Study from the Italian Listed Companies, Accounting and Finance Research, 6 (2), 121-135. https://doi.org/10.5430/afr.v6n2p121.

Carels, C., Moroun, W., \& Padia, N. (2013). Integrated Reporting in the South African Mining Sector, Virtus Nter Press, Corporate Ownership \& Control, 11 (1), 947-961. http://doi.org/10.22495/cocv11i1c11p6.

CLGir (2016). Forging a path to integrated reporting - Insights from the GRI Corporate Leadership Group on Integrated Reporting. GRI Empowering Sustainable Decisions. Amsterdam. The Netherlands.

CSREU (2017). Your Manual on the EU Directive for the Disclosure on Non-Financial Information, CSR Europe - Corporate Social Responsibility Europe \& Enterprise 2020.

De Villiers, C., Rinaldi, L., \& Unerman, J.(2014). Integrated Reporting: Insights, gaps and an agenda for future research. Accounting, Auditing \& Accountability Journal, 27(7), 1042-1067. http://dx.doi.org/10.1108/AAAJ-06-2014-1736.

Dumitru, M., Glavan, M.E., Gorgan, C., \& Dumitru V.F. (2013). International Integrated Reporting Framework: A Case Study in the Software Industry, Annales Universitatis Apulensis Series Oeconomica, 15 (1), 24-39.

Eccles, R.G. \& Spiesshofer, B.(2015). Integrated Reporting for a Re-Imagined Capitalism. Harvard Business School, Working Paper No 16.032.

Eccles, R.G., \& Serafeim, G. (2014). Corporate and Integrated Reporting: A Functional Perspective. Harward Business School, Working Paper, 14-094, 1-15. 
EUDNFI (2014). Directive 2014/95/EU, Official Journal of the European Union. Text with EEA relevance. http://eur-lex.europa.eu/legal-content/EN/TXT/PDF/?uri=CELEX: 32014L0095\&from=HR (accessed: 02.06. 2015).

EY (2014). Integrated reporting - Elevating value. EY - Building a better working world. EYGM Limited. EYG No. AU2354.

Gorgan, C., Dumitru, V.F., \& Gorgan, V. (2014). Key Performance Indicators. A Case Study on the Integrated Reports of an IT Company, Annals of the "Constantin Brancusi" University of Targu Jiu, Economy Series, 3, 111-118.

GRI (2016). GRI 101: Foundation 101. GRI Global, GRI 101 (1), 29. https://www.globalreporting.org/standards/gri-standards-download-center/ (accessed: 14. 01. 2017).

GRI G4 (2015). G4 Sustainability Reporting Guidelines - Reporting Principles and Standard Disclosures, The Global Sustainability Standards Board (GSSB). Amsterdam, Netherlands www.globalreporting.org.

GRIs (2016). The Next Era of Corporate Disclosure - Digital, Responsible, Interactive, Sustainability and Reporting 2025 Project: GRI - Empowering Sustainable Decisions, Amsterdam The Netherlands. www.globalreporting.org.

Hoque, M.E. (2017). Why Company Should adopt Integrated Reporting. International Journal of Economics and Financial Issues, 7 (1), 241-248.

Hoque, Z. (2006). Strategic Management Accounting, Concepts, Processes and Issues, 2nd Edition, Australia: Pearson Education Australia, Frenchs Forest.

IFAC (2015). Materiality in IR - Guidance for the preparation of integrated reports. IR_Integrated Reporting. IFAC - International Federation of Accountants.

IIRC (2013). Business and Investors explore the sustainability perspective of Integrated Reporting. The IIRC Pilot Programme Yearbook 2013. http://integratedreporting. org/wp-content/uploads/2013/12/IIRC-PP-Yearbook-2013_PDF4_PAGES.pdf (accessed: 22.05.2017).

IIRC (2016). Journey to Breakthrough, IIRC Integrated Report 2016. http://integratedreporting.org/wp-content/uploads/2017/07/IIRC_IR2016_IntegratedReport.pdf (accessed 22.05.2017).

IR (2016). Creating Value - The cyclical power of integrated thinking and reporting, IIRC - The International Integrated Reporting Council. http://integratedreporting.org/ wp-content/uploads/2016/11/ CreatingValue_IntegratedThinking_.pdf (accessed: 15. 01. 2017).

IR Framework (2013). The International "IR" Integrated Reporting Framework, The International Integrated Reporting Council (IIRC). https://integratedreporting. org/wp-content/uploads/2013/12/13-12-08-THE-INTERNATIONAL-IR-FRAMEWORK-2-1.pdf (accessed: 29. 03. 2015).

Jones, T., Atkinson, H., Lorenz, A., \& Harris, P. (2012). Strategic Managerial Accounting Hospitality, Tourism \& Events Applications, 6Ed, Goodfellow Publishers, Ltd.

Mio, Ch. (Ed.) (2016). Integrated Reporting - A New Accounting Disclosure, Palgrave Macmillan Publishers Ltd. London, https://doi.org/10.1057/978-1-137-55149-8.

Peršić, M., \& Halmi, L. (2016). Disclosing non-financial information in companies' reports in Croatia, Copernican Journal of Finance \& Accounting, 5 (2), 181-200. http:// dx.doi.org/10.12775/CJFA.2016.022. 
PWC (2012). Integrated Reporting - The Future of Corporate Reporting - A guide on integrated reporting highlighting the kay content elements and principles of good reporting practices for your company. AG Wirtschaftsprüfungsgesellschaft. PricewaterhouseCoopers.

PWC (2015). Implementing Integrated Reporting - PWC's practical guide for a new business language. PricewaterhouseCoopers LLP. UK.

SASB (2017). SASB Rules of Procedure, Sustainability Accounting Standard Board (SASB), San Francisco, CA, USA.

Serafeim, G. (2016) Integrated Reporting - Statement on Management Accounting, IMA The Association of Accountants and Financial Professionals in Business, The Americas, Asia/Pacific, Europe and Middle East/Africa, Montvale, NJ.

Valamar (2015). Integrated Company Annual Report and Corporate Social Responsibility, Valamar Riviera, Poreč, Croatia, 1-58, http://valamar-riviera.com/en/investors/financial-news/integrated-company-annual-report-and-corporate-social-responsibility-2015/ (accessed: 24. 02. 2017).

Valamar (2016). Integrated Company Annual Report and Corporate Social Responsibility, Valamar Riviera, Poreč, Croatia, 1-174, http://valamar-riviera.com/media/139229/ integrated-company-annual-report-and-corporate-social-responsibility-2016.pdf (accessed: 24. 02. 2017). 